FLOODS OF MAY TO JUNE 1983 ALONG THE

NORTHERN WASATCH FRONT, SALT LAKE CITY

TO NORTH OGDEN, UTAH

By K. L. Lindskov

U.S. GEOLOGICAL SURVEY

Open-File Report 84-456

Prepared in cooperation with the

UTAH GEOLOGICAL AND MINERAL SURVEY

Salt Lake City, Utah

1984 


\section{UNITED STATES DEPARTMENT OF THE INTERIOR \\ WILLIAM P. CLARK, Secretary}

GEOLOGICAL SURVEY

Dallas L. Peck, Director

For additional information

write to:

District Chief

U.S. Geological Survey

Room 1016, Administration Bullding

1745 West 1700 South

Salt Lake City, Utah 84104
Coples of this report can be purchased from:

Open-File Services Section Western Distribution Branch U.S. Geological Survey Box 25425, Federal Center Denver, Colorado 80225

(Telephone: (303)234-5888) 
Page

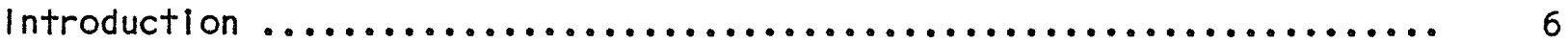

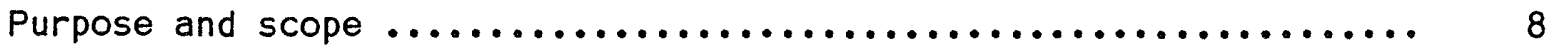

Previous investigations ............................... 8

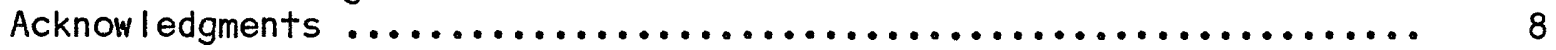

General hydrologic condltions that produced the floods ............. 8

Determination of magnitude and frequency of peak discharge ........... 9

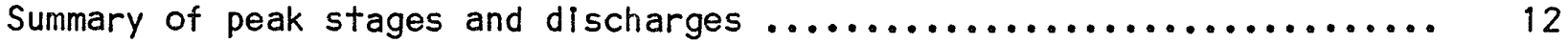

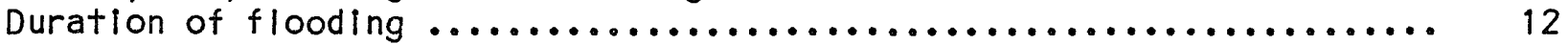

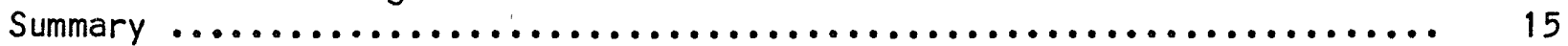

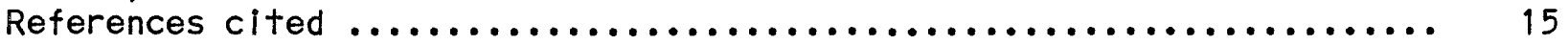

\section{ILLUSTRATIONS}

Figure 1. Index map of Utah showing location of the Wasatch Front ..... 6

2. Map showing location of sites for measurements of flood and climatologic data ............................ 6

3. Map depicting high-flow conditions defined by comparing streamflow into Great Salt Lake in the major rivers from October 1982 to May 1983 with average streamflow for October to May .................. 9

4-7. Graphs showing:

4. Comparison of water content of snowpack during 1983 with average for January to May 1963-77 for two river basins and one snow course ............... 9

5. Daily range in air temperature at low- and highaltitude sites, April to June 1983 ................

6. Comparison of floods during May to June 1983 with maximum previously known floods determined

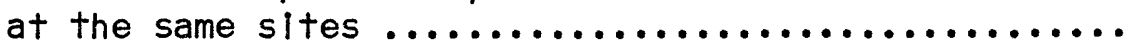

7. Relation of highest mean discharge for indicated number of consecutive days to the peak discharge

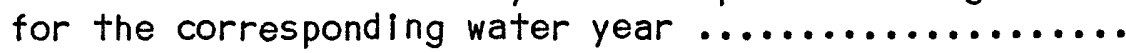

\section{TABLES}

Table 1. Summary of peak stages and discharges for 11 streams along the northern Wasatch Front, May to June 1983

2. Summary of ratios of highest mean discharge for 3and 30-consecutive days to annual peak discharge 


\section{CONVERSION FACTORS}

Values in this report are given in inch-pound units. Conversion factors to metric units are listed below:

\section{Multiply}

cubic foot per second $\left(f t^{3} / \mathrm{s}\right)$

cubic foot per second

per square mile

$\left.\left[\left(f t^{3} / s\right) / m i^{2}\right)\right]$

inch

foot $(f t)$

mile $(\mathrm{mi})$

square mile $\left(m i^{2}\right)$
By

0.02832

0.01093

25.40

0.3048

1.609

2.590
Io obtain

cub ic meter per second cubic meter per second per square kilometer

millimeter

meter

kllometer square kilometer

Air temperature is given in degrees Fahrenheit $\left({ }^{\circ} \mathrm{F}\right)$, which can be converted to degrees Celslus $\left({ }^{\circ} \mathrm{C}\right.$ ) by the following equation:

$$
{ }^{\circ} \mathrm{C}=\left({ }^{\circ} \mathrm{F}-32\right) / 1.8
$$

National Geodetic Vertical Datum of 1929 (NGVD of 1929): A geodetic datum derived from a general adjustment of the first-order level nets of both the United States and Canada, formerly called mean sea level, is referred to as sea level in this report. 


\title{
FLOODS OF MAY TO JUNE 1983 ALONG THE NORTHERN WASATCH FRONT, SALT LAKE CITY TO NORTH OGDEN, UTAH
}

\author{
By K. L. Lindskov
}

\section{ABSTRACT}

Determinations of peak discharge for floods of May to June 1983 were made for 11 streams along the northern Wasatch Front from Salt Lake City to North Ogden. At nine of the streams, the floods during the spring of 1983 equaled or exceeded the 100-year flood. The peak discharge at Stone Creek was 40 times the maximum previously known flood, and the peak discharges at the other sites ranged from slightly greater to about five times that previously known. In addition to the outstanding peak discharges, streamflow at the 11 sites commonly remains high for days, weeks, or even a month.

The floods resulted from retention of an abnormally large snowpack until rain combined with above normal temperature caused rapid melting. The peak discharges and continued high flows damaged homes, highways, and drainage canals.

\section{INTRODUCTION}

The Wasatch Front in Utah extends from Brigham City on the north to Nephi on the south (fig. 1). It includes the western flank of the Wasatch Range and the densely populated eastern part of the adjoining valleys at the base of the range. Outstanding floods, which occurred during late May and early June 1983 on streams along the northern Wasatch Front in Davis, Salt Lake, and Weber Counties (fig. 2), resulted from retention of an abnormally large snowpack until rain combined with above normal temperature caused rapid melting. The peak discharge and continued high flow of streams in the foothills damaged homes, highways, and drainage canals and disrupted services to some areas. In addition, debris flows and debris floods caused considerable damage in populated areas between Salt Lake City and North Ogden.

It is important to distinguish between debris flows and debris floods because mitigating procedures for one may be ineffective for the other. Debris flows are mass movements in which water and soil materials including large rocks, combine to form a muddy slurry much like wet concrete. The mass is more viscous than flowing water, and it moves with a front armored with material that can range up to boulder-size. Debris floods are not as viscous and consist of soll materials mixed with greater relative proportions of water, all of which are transported swiftly by the moving water. Deposits from debris floods can be distinguished from those of debris flows by the greater degree of sorting associated with the debris floods. For a more detalled distinction between debris flows and debris floods, see costa and Jarrett (1981, p. 310-312). This report deals with debris floods, which can be considered as waterfloods with large sediment loads. 
Figure 1.--Index map of Utah showing location of the Wasatch Front. Figure 2.--Location of sites for measurements of flood and climatologic data. 


\section{Purpose and Scope}

Local, State, and Federal offlcials need factual information to evaluate, coordinate, and manage programs relating to flood damage. This report was prepared in cooperation with the Utah Geological and MIneral Survey to provide a summary of the extent and magnitude of floods along the Wasatch Front where the Utah Geological and Mineral Survey is considering measures to mitigate debris floods. This report includes information on magnitude and frequency of peak stages (gage heights or water-surface elevations) and discharges and relations for estimating volumes of streamflow for durations of 3 and 30 days. The information, which is tabulated for 11 streams, represents waterfloods with large sediment loads.

\section{Previous Investigations}

Numerous debris floods have occurred in canyons along the Wasatch Front in Davis, Salt Lake, and Weber Countles, and they have been documented by Butler and Marsell (1972), Croft (1967, 1981), and Wool ley (1946). The impact of flooding during the 1920's and 1930's resulted in the formation of the Davis County Experimental Watershed and the construction of erosion-control features in the headwaters of many canyons and flood-mitigation structures near the canyon mouths. The U.S. Army Corps of Engineers $(1969,1974)$ and the U.S. Department of Housing and Urban Development (1978) completed flood-plain studies for streams in the area. Dass and others (1982) summarized the hydrology of floods for 20 northern Utah communities, Including several in the area studied for this report. Wieczorek and others (1983) give a preliminary appraisal of the potential for debris flows, debris floods, and landslides in canyons in the study area, and they also discuss means of mitigating the hazards.

\section{Acknowledgments}

The assistance of the National Weather Service, National Oceanic and Atmospheric Administration; the U.S. Soil Conservation Service; and the U.S. Forest Service in providing precipitation data and recommendations for presenting it is appreclated. I wish to thank George E. Pyper and Howard F. McCormack of the U.S. Geological Survey for making indirect measurements of peak discharge and for many of the computations that resulted in the data presented in this report.

\section{GENERAL HYDROLOGIC CONDITIONS THAT PRODUCED THE FLOODS}

The May to June 1983 floods along the northern Wasatch Front were caused by rain and above normal temperature that resulted in rapid melting of an abnormally large snowpack. The snow depth at 8,000 feet in Farmington Canyon on May 27, 1983, was 102 inches, with a water content of 51.8 inches (U.S. Soll Conservation Service, 1983), more than 400 percent of the normal of 12.4 inches. More than 0.4 inch of rain was recorded on June 1, 1983, at the Utah State University Field Station in Farmington (National Oceanic and Atmospheric Administration, 1983). 
The most important conditions that determined the degree of flooding were (1) high-flow conditions at the start of the winter, as evidenced by above average streamflow during the winter months ( $f i g .3)$, (2) retention of snowpack at intermediate altitudes (6,000-7,000 feet) during early spring because of lower than normal temperatures (fig. 4), (3) above normal precipitation during May, (4) above normal temperatures at the end of May, which caused rapid snowmelt (fig. 5), and (5) ralnfall on June 1, which increased melting.

\section{DETERMINATION OF MAGNITUDE AND FREQUENCY OF PEAK DISCHARGE}

The peak stage and discharge are summarized in table 1 for sites on 11 streams. Nine of the sites are at gaging stations, of which two were active during 1983 and seven were discontinued. The other two, stations 10140480 and 10140900, are miscellaneous sites (lacking systematic records of peak or daily discharge). Peak discharges for the two active sites were determined from stage-discharge relations defined by current-meter measurements made near enough to the peak so that reliable extensions of the relations were possible. Peak discharges at the discontinued gaging stations and miscellaneous sites were determined by indirect methods, including surveys for the slope-area, flow-through-culvert, and critical-depth methods (Benson and Dalrymple, 1968). The indirect methods were necessary for the nine sites because the stagedischarge relations were not adequately defined as no current-meter

measurements were obtained in 1983 at these sites. Where possible, the stages or gage heights of the 1983 flood were referenced to the datum in use when the station was discontinued.

The flood-frequency relations reported by Thomas and Lindskov (1983) were used to determine the recurrence intervals (the average intervals of time, in years, within which given floods will be equaled or exceeded once) of the 1983 peak discharges. Station data, excluding the 1983 values (table 12 of Thomas and Lindskov, 1983), were used for the nine sites with 17 years or more of record. The techniques for deriving these frequency relations from station data are described by the U.S. Water Resources Councll (1981). Estimates computed from equations I isted by Thomas and Lindskov (1983, p. 19) were used to determine the recurrence intervals of the 1983 peak discharge for the two miscellaneous sites. Frequencies of peak discharge were estimated for recurrence intervals of 100 years or less; for greater values, recurrence intervals are noted only as "greater than 100 years." 





Figure 3.--High-flow conditions defined by comparing streamflow into Great Salt Lake in the major rivers from October 1982 to May 1983 with average streamflow for October to May. From Arnow (1984, fig. 9).

Figure 4.--Comparison of water content of snowpack during 1983 with average for January to May 1963-77 for two river basins and one snow course. Data from U.S. Soll Conservation Service (1983).

Figure 5.--Dally range in air temperature at low- and high-altitude sites, April to June 1983. Data from National Oceanic and Atmospheric Administration (1983). 
Peak stage and discharge were documented at the 11 sites along the northern Wasatch Front (fig. 2). Cold Water Creek and Coldwater Creek in Coldwater Canyon drain to the Ogden and Weber Rivers near Ogden and North Ogden. Holmes, Farmington, Ricks, Parrish, Centerville, Stone, and Mill Creeks are tributaries to the Great Salt Lake between the Weber and Jordan Rivers. Red Butte and City Creeks drain to the Jordan River in Salt Lake City.

Peak stages and discharges for the 11 sites are presented in table 1 for the maximum previously known flood and for the flood in May to June 1983. The relative magnitude of the 1983 floods compared to the maximum previously known is shown in figure 6. The 1983 floods exceeded the maximum previously known floods at all nine sites with record prior to 1983 . Other than for Stone Creek, the 1983 floods ranged from slightly larger than to about five times that previously known. The exceptional flooding in stone Creek, which was 40 times that previously known, probably resulted from a sudden release of water ponded behind a landslide. At 9 of the 11 sites, the 1983 flood equaled or exceeded the 100-year flood (the flood expected to be equaled or exceeded once every 100 years, on the average).

\section{DURATION OF FLOODING}

In addition to the outstanding peak discharges, streamflow at the 11 sites commonly remains high for days, weeks, or even a month. This can be illustrated by using the daily discharge records and comparing the highest mean discharge for a few days and a month to the corresponding peak discharge. An example is shown in figure 7 for station 10141500, Holmes Creek near Kaysville. At that station, the highest mean discharge for 3 consecutive days is about 0.8 of the peak discharge and for 30 days it is about 0.6 of the peak discharge. Relationships between the highest mean discharge for 3- and 30consecutive days were calculated for nine sites, and the results are summarlzed in table 2. The highest mean discharge, for 3-consecutive days ranged from about 0.5 to 1.0 of the peak discharge, and for 30 days the ratios ranged from 0.3 to 0.8 .

The volumes of streamflow from floods along the Wasatch Front are large when compared to the peak discharges. This is typical of flooding from snowmelt. Infrequent thunderstorms of great intensity can cause large floods in these streams; however, discharges recede quickly, and flooding does not last long. During the perlod of record shown in table 1, only one annual peak discharge resulted from a thunderstorm--at station 10141500, Holmes Creek near Kaysville. 
Table 2.--Summary of ratios of highest mean discharge for 3- and 30consecutive days to annual peak discharge

Ayerage ratio: Determined from Il near-regression analysis. $\mathrm{R}^{2}$ : The correlation coefficient squared.

\begin{tabular}{|c|c|c|c|c|c|}
\hline \multirow{3}{*}{ Station No. } & \multirow{3}{*}{$\begin{array}{l}\text { Perlod of } \\
\text { record used } \\
\text { (water years) }\end{array}$} & \multicolumn{4}{|c|}{ Consecutive days } \\
\hline & & \multicolumn{2}{|c|}{3} & \multicolumn{2}{|c|}{30} \\
\hline & & $\begin{array}{c}\text { Average } \\
\text { ratlo }\end{array}$ & $\mathrm{R}^{2}$ & $\begin{array}{c}\text { Average } \\
\text { ratio }\end{array}$ & $\mathrm{R}^{2}$ \\
\hline 10141500 & $1950-66$ & 0.8 & 0.92 & 0.6 & 0.90 \\
\hline 10142000 & $1950-80$ & .5 & .88 & .3 & .74 \\
\hline 10142500 & $1951-66$ & .7 & .91 & .4 & .85 \\
\hline 10143000 & $1950-68$ & .8 & .96 & .5 & .95 \\
\hline 10143500 & $1950-80$ & .9 & .98 & .7 & .97 \\
\hline 10144000 & $1951-66$ & a. 6 & .92 & a. 4 & .87 \\
\hline 10145000 & $1951-68$ & .6 & .95 & .4 & .93 \\
\hline 10172200 & $1964-82$ & .9 & $>.99$ & .6 & .93 \\
\hline 10172500 & $\begin{array}{l}1964-68, \\
1980\end{array}$ & 1.0 & .97 & .8 & .87 \\
\hline
\end{tabular}

a The 1983 peak discharge probably resulted from a sudden release of water ponded behind a landslide. This average ratio is based on historic values and does not apply to 1983. 
Figure 6.--Comparison of floods during May to June 1983 with maximum previously known floods determined at the same sites.

Figure 7.--Relation of highest mean discharge for indicated number of consecutive days to the peak discharge for the corresponding water year. Data for station 10141500, Holmes Creek near Kaysville. 
The information for volumes of streamflow or duration of flooding is useful for designing structures for mitigating debris floods. The ratios given in table 2, however, should be used with caution for estimating volumes of extreme floods. For example, the extreme peak discharge for Stone Creek and the ratios in table 2 should not be used to estimate the highest mean discharge for 3- and 30-days for the 1983 flood. The extreme peak discharge for Stone Creek probably resulted from a sudden release of water similar to a dam fallure, thus, the duration of the extreme peak discharge was probably less than 1 hour.

\section{SUMMARY}

Peak stage and discharge of the May to June 1983 flood were documented at 11 sites along the northern Wasatch Front. At 9 of the 11 sites, the 1983 floods equaled or exceeded the 100-year flood. The 1983-peak discharge for Stone Creek was 40 times the maximum previously known flood, and at the other sites the peak discharge ranged from slightly greater to about five times that previously known. In addition to the outstanding peak discharge, streamflow at the 11 sites commonly remains high for days, weeks, or even a month.

The floods resulted from retention of an abnormally large snowpack until rain combined with above normal temperature caused rapid melting. The peak discharges and continued high flows damaged homes, highways, and drainage canals.

\section{REFERENCES CITED}

Arnow, Ted, 1984, Water-level and water-quality changes in Great Salt Lake, Utah, 1847-1983: U.S. Geological Survey Circular 913, 22 p.

Benson, M. A., and Dalrymple, Tate, 1968, General field and office procedures for indirect discharge measurements: U.S. Geological Survey Techniques of Water-Resources Investigations, Book 3, Chapter A1, 30 p.

Butler, Elmer, and Marsel I, R. E., 1972, Cloudburst floods in Utah, 1939-69: Utah Division of Water Resources Cooperative Investigations Report 11 , $103 \mathrm{p}$.

Costa, J. E., and Jarrett, R. D., 1981, Debris flows in small mountain stream channels of Colorado and their hydrologic implications: Bulletin of the Association of Engineering Geologists, v. XVIII, no. 3, pp. 309-322.

Croft, A. R., 1967, Rainstorm debris floods, a problem in public welfare: University of Arizona, Agricultural Experiment Station, Report 248, 36 p.

1981. History of development of the Davis County Experimental Watershed: U.S. Department of Agriculture, Forest Service, Intermountain Region (Region Four), Ogden, Utah, 42 p. 
Dass, Puroshottam, Lambert, R. L., and Clement, D. D., 1982, Flood hydrology of streams in northern Utah: American Water Resources Association Symposium on Hydrometeorology, June 13-17, 1982, Denver, Colorado, 12 p.

National Oceanic and Atmospheric Administration, 1983, Environmental Data Service, Climatological data, Utah, 1983: v. 85, nos. 1-6.

Thomas, B. E., and Lindskov, K. L., 1983, Methods for estimating peak discharge and flood boundaries of streams in Utah: U.S. Geological Survey Water-Resources Investigations Report 83-4129, 77 p.

U.S. Army Corps of Engineers, 1969, Flood plain information; Barton, Mill, and Stone Creeks, Bountiful, West Bountiful, and Woods Cross, Utah: U.S. Army Corps of Engineers, Sacramento, Call fornia, 35 p.

1974, Flood plain information; Farmington Bay tributaries, FarmingtonCenterville, Utah: U.S. Army Corps of Engineers, Sacramento, Californla, $50 \mathrm{p}$.

U.S. Department of Housing and Urban Development, 1978, Flood insurance studies, City of Bountiful, Utah: U.S. Department of Housing and Urban Development Federal Insurance Administration, 21 p., $13 \mathrm{pl}$.

U.S. Soll Conservation Service, 1983, Water supply outlook for Utah, June 1, 1983, monthly January to June. U.S. Department of Agriculture, Salt Lake City, Utah.

U.S. Water Resources Council, 1981, Guldelines for determining flood flow frequency: U.S. Water Resources Councll Bulletin 17B, 28 p. ,14 appendixes.

Wieczorek, G. F., and others, 1983, Potential for debris flow and debris flood along the Wasatch Front between Salt Lake City and Willard, Utah, and measures for their mitigation: U.S. Geological Survey Open-File Report $83-635,25 \mathrm{p}$.

Woolley, R. R., 1946, Cloudburst floods in Utah, 1850-1938: U.S. Geological Survey Water-Supply Paper 994, $128 \mathrm{p}$. 


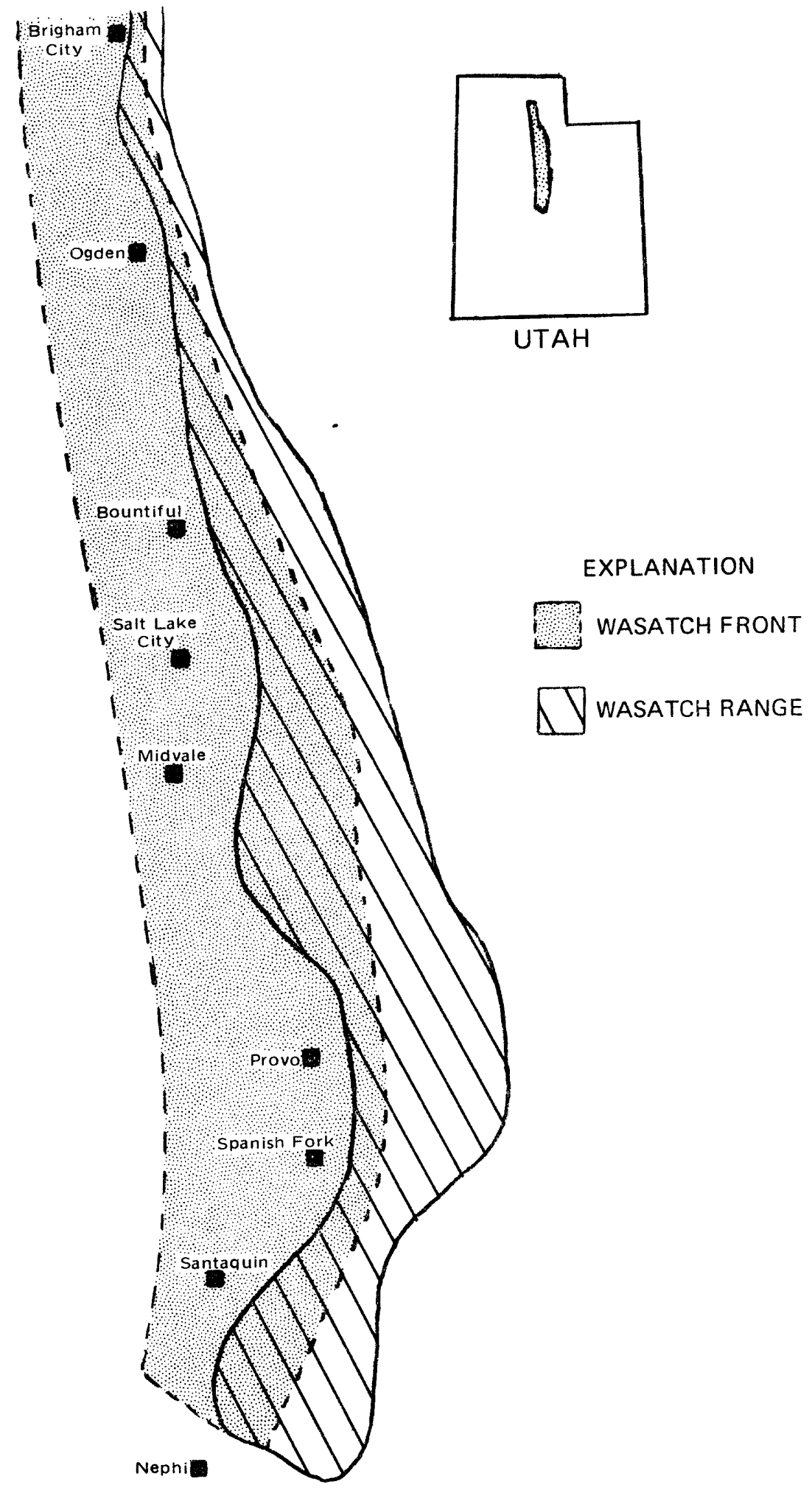

Figure 1.-Index map of Utah showing location of Wasatch Front. 


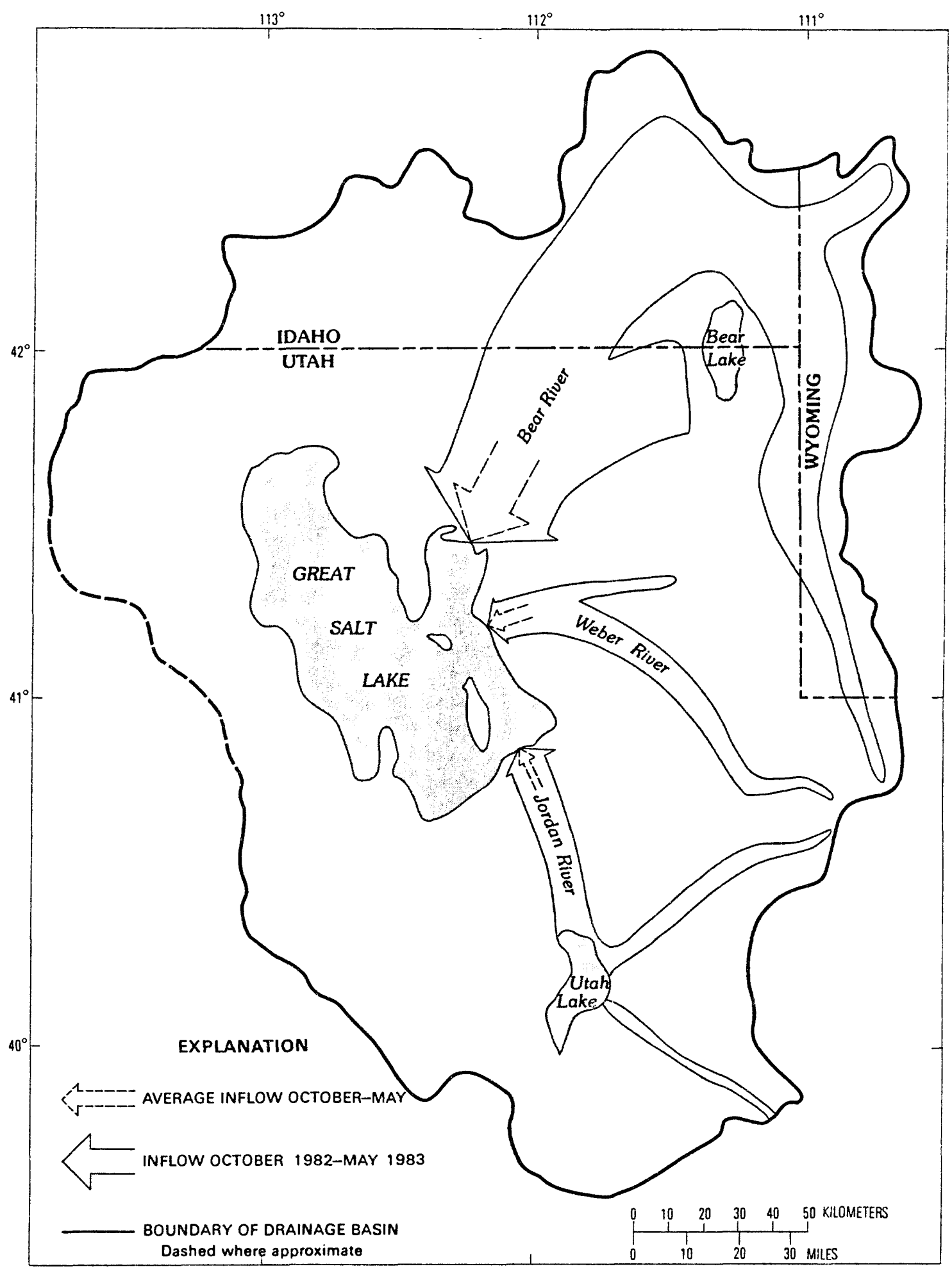

Figure 3.-- High-flow conditions defined by comparing Utreamflow into Great vart Lake in the major rivers from actaber 1982 to May 1983 with average Gtrean flow for Odaber to May. From Arnow (198\%, tis.9). 


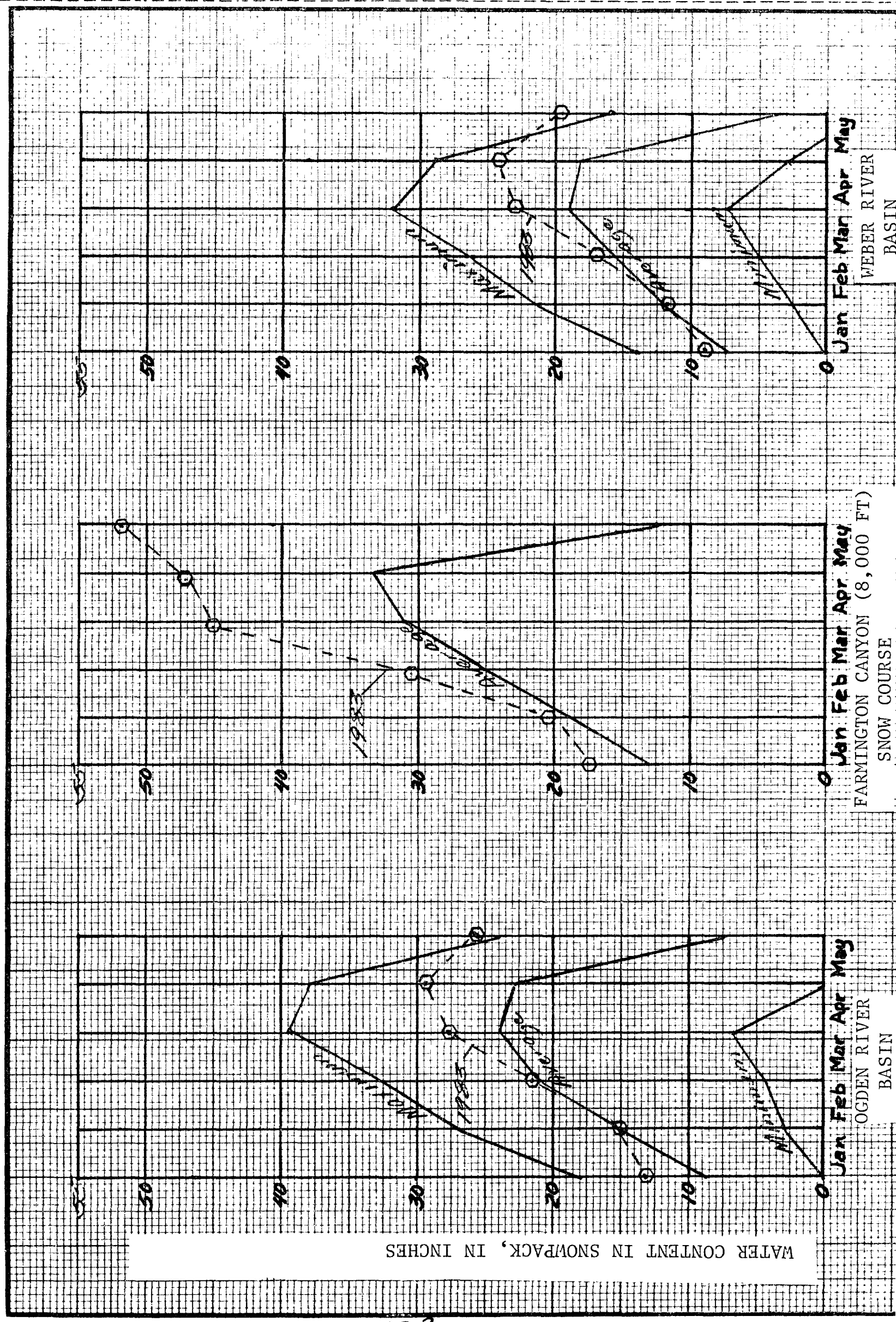




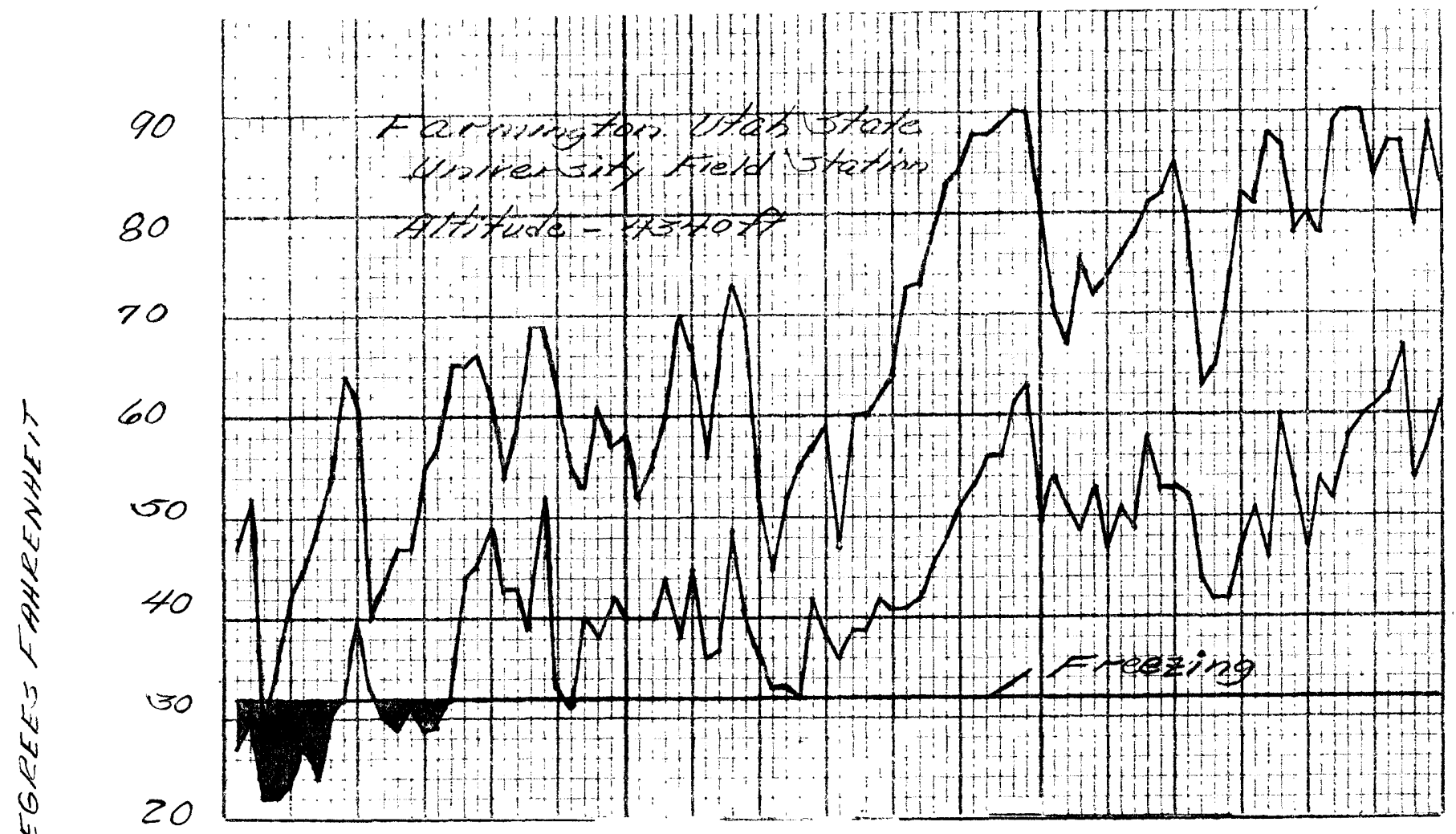

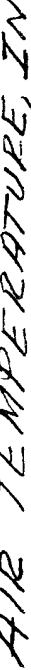

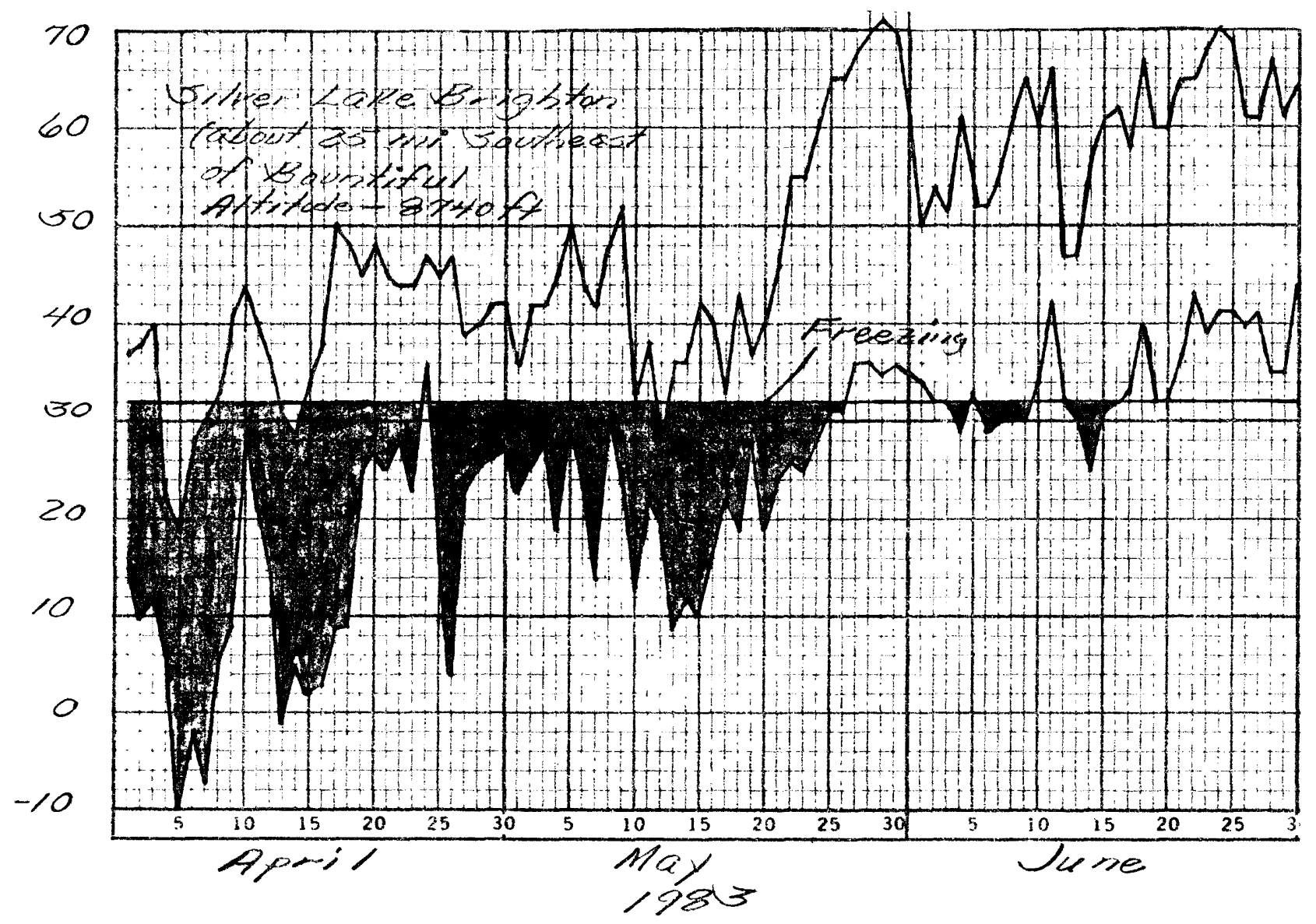

Figure 5.- Daily range is air temperature at lowand hish-altitude vitespribata from National Oceanic and Atmospheric Administration (1983). 







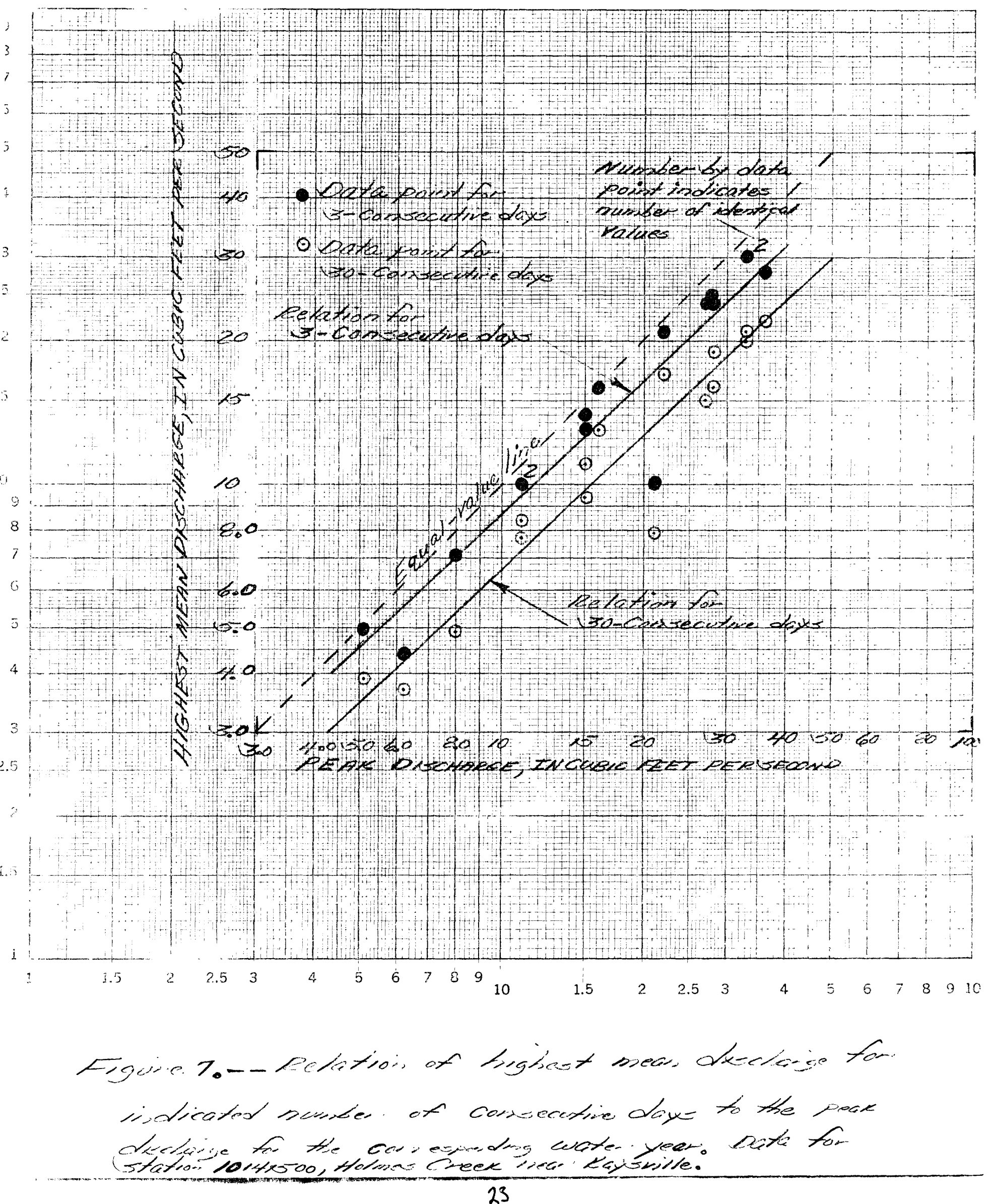

